\title{
IIST OF ABBREVIATIONS
}

The following is a listing of some of the more frequently used abbreviations in the book.

ACLU American Civil Liberties Union

AFL American Federation of Labor

BAC Bay Area Council

BACAD Bay Area Council Against Discrimination

BART Bay Area Rapid Transit

$\mathrm{CCIH} \quad$ California Commission of Immigration and Housing

CCU Council for Civic Unity

CHPA California Housing and Planning Association

$\mathrm{CIO} \quad$ Congress of Industrial Organizations

CREA California Real Estate Association

FEPC Fair Employment Practices Committee

FHA Federal Housing Administration

FPHA Federal Public Housing Authority

HHFA Housing and Home Finance Agency

HOPE I Homeownership and Opportunity for People Everywhere

HOPE SF Homeownership and Opportunity for People

Everywhere San Francisco

HOPE VI Homeownership and Opportunity for People Everywhere VI

HPTU Hunters Point Tenants Union

HUD Department of Housing and Urban Development

ILWU International Longshoremen and Warehouse Union

IWW Industrial Workers of the World

NAACP National Association for the Advancement of Colored People 
NAHRO National Association of Housing and Redevelopment Officials

NAREB National Association of Real Estate Brokers

NHA National Housing Association

NTO National Tenants Organization

OEO Office of Economic Opportunity

PHA Public Housing Agency

PILOT payment in lieu of taxes

PWA Public Works Administration

RMC resident management corporation

SCWC Senior Citywide Council

SFHA San Francisco Housing Authority

SFHRC San Francisco Human Rights Commission

SFPHA San Francisco Planning and Housing Association

SPUR San Francisco Urban Renewal (Research) Association

SFPHTA San Francisco Public Housing Tenant Association

SMUF South of Market United Front

SRO single-room occupancy housing

TODCO Tenants and Owners Development Corporation

TOOR Tenants and Owners in Opposition to Redevelopment

USHA United States Housing Authority

WACO Western Addition Community Organization

WPA Works Progress Administration

YBTU Yerba Buena Tenants Union 


$$
-
$$


This page intentionally left blank 